\title{
Why Do Some Civil Wars Last So Much Longer Than Others?*
}

\author{
James D. Fearon \\ Department of Political Science \\ Stanford University \\ Stanford, CA 94305-6044
}

November 13, 2003

*E-mail address: jfearon@stanford.edu. The author gratefully acknowledges the financial support of the World Bank's PostConflict Fund and research assistance by Moonhawk Kim and Nikolay Marinov. This paper draws on data developed and work in progress with David Laitin, whom I thank for many helpful comments and discussions. I also thank Robert Powell and seminar audiences at the University of Michigan, U.C. Berkeley, and Harvard University for helpful comments. The data used in this article can be found at http://www.stanford.edu/group.ethnic/. 


\begin{abstract}
Five factors are shown to be strongly related to civil war duration. Civil wars emerging from coups or revolutions tend to be short. Civil wars in Eastern Europe and the former Soviet Union have also tended to be relatively brief, as have anticolonial wars. By contrast, 'sons of the soil' wars that typically involve land conflict between a peripheral ethnic minority and state-supported migrants of a dominant ethnic group are on average quite long-lived. So are conflicts in which a rebel group derives major funding from contraband such as opium, diamonds, or coca. The paper seeks to explain these regularities, developing a game model focused on the puzzle of what prevents negotiated settlements to long-running, destructive civil wars for which conflicting military expectations are an implausible explanation. In the model, regional autonomy deals may be unreachable when anticipated fluctuations in state strength undermine the government's ability to commit. The commitment problem binds harder when the center has an enduring political or economic interest in expansion into the periphery, as in 'sons of the soil' wars, and when either government or rebels are able to earn some income during a conflict despite the costs of fighting, as in the case of contraband funding.
\end{abstract}




\section{Questions}

At the highwater mark in 1994, there were 44 on-going civil wars in almost one-quarter of the states in the international system. ${ }^{1}$ This peak did not, however, represent the sudden appearance of civil war as a major international political problem with the end of the Cold War. The number of ongoing civil wars had been steadily, almost linearly increasing from 1945 up to 1991 (see Figure 1). The collapse of the Soviet Union was associated with an upsurge of civil wars in the early 90s, but it was an upsurge from an already high level.

What accounts for this steady upward trend? Have violent civil conflicts broken out and ended at higher and higher rates over time? Or is the rate of onset significantly higher than the rate of settlement, leading to an accumulation of unresolved wars? As noted in Fearon and Laitin (2003), civil wars have been breaking out in this period at a rate of about 2.3 per year, and ending at a rate of about 1.85 per year. Another way to put this is that the average duration of civil wars in progress has been steadily increasing throughout the post-war period, reaching almost 16 years in 1999 (see Figure 1). These observations suggest that the prevalence of civil war as an international blight is due in major part to the difficulty of ending such conflicts.

Why are so many civil wars so difficult to end? A natural place to look for an answer is variation in the duration of civil wars, which is remarkably large. According to the data considered below, a quarter of the 128 civil wars starting since 1945 lasted two years or less, and a quarter of all civil wars have lasted at least 12 years. Thirteen wars in the sample are coded as having lasted at least 20 years.

To understand why some (and so many) civil wars drag on it makes sense to compare these in a systematic fashion to civil wars that end more quickly. This paper represents a first cut effort at such a comparison.

Perhaps the question has a simple answer: Civil wars last a long time when neither side can disarm the other, causing a military stalemate. They are relatively quick when conditions favor a decisive victory.

Though this answer verges on tautology, it is a productive tautology in that it provokes some interesting theoretical and empirical puzzles. First, what exactly are the conditions that favor a military stalemate in a civil war, or conversely, a quick military victory? Second, if conditions favor a decisive victory by one side, why is a war fought at all? Why doesn't the disadvantaged side not even contest the issue? Third, if conditions favor a stalemate, then wouldn't the parties have a strong incentive to cut a deal (Zartman 1989), tending to

\footnotetext{
${ }^{1}$ See the data in Fearon and Laitin (2003). The criteria defining 'civil war' for this study are discussed below and in that article.
} 
neutralize the effect of military conditions on the duration of the war? So why shouldn't civil war duration be independent of the military and political conditions that bear on the likelihood that one side can disarm the other?

In pursuing answers to these questions, I work back and forth between empirical evidence and theoretical arguments. The second section introduces the data set used and considers some questions about how civil war duration should be defined and coded.

In the third section, I identify five classes of civil wars that have tended to end either more quickly or more slowly than most others. ${ }^{2}$ I find that: (1) civil wars arising out of coup attempts and popular revolutions are usually quite brief. (2) Anticolonial wars have also been relatively brief. Cases of what I will call peripheral insurgencies - civil wars involving rural guerrilla bands typically operating near the state's borders - have, with a few interesting exceptions, been remarkably difficult to end. (3) One interesting class of exceptions are the wars arising out the break-ups of the Soviet Union and Yugoslavia, which have been relatively short-lived. (4) Among peripheral insurgencies, cases involving 'sons of the soil' dynamics - land or natural resource conflicts between a peripheral ethnic minority and statesupported migrants of a dominant ethnic group - are on average quite long-lived. (5) So, it appears, are conflicts in which the rebel group has access to funds from contraband such as opium, diamonds, or coca. Section 3 closes with a demonstration that standard candidates for predicting civil war duration (ethnic diversity, per capita income, level of democracy, and 'ethnic' vs. 'ideological' war) have little or no independent power once we control for the above factors.

In the fourth section, I propose theoretical arguments to try to make sense of these diverse empirical regularities. I argue that coups and popular revolutions favor decisive victories because they tend to be initiated at the center in the hope of triggering a tipping process, whose outcome is a lottery. Potential coup leaders can't negotiate deals in preference to the coup lottery because the offer to do so would lower their odds in the lottery to practically nil, eliminating their bargaining power (and possibly their lives).

Peripheral insurgencies, by contrast, are military contests where the main aims are to render the other side unable to fight or to impose costs that motivate the other side to negotiate a favorable settlement. An imbalance of military capabilities ought to predict a higher chance of a decisive victory; but conceptualizing and measuring the 'balance' between guerrillas and a state, independent of the outcome, is quite difficult. In the fifth section I develop a game model that does not resolve this question, but does elaborate an answer to the question above about the prospects for negotiated settlements. In the model, under some circumstances mutually beneficial regional autonomy agreements are rendered impossible

\footnotetext{
${ }^{2}$ These categories are not mutually exclusive - some civil wars in the data set have more than one of the five attributes.
} 
by the rebels' expectation that the government would renege on the deal when it regains strength. The results explain how it is possible to have a long-running, costly civil war for which it is implausible to argue that the main obstacle to a settlement is over-optimistic military expectations on both sides (cf. Blainey (1973), Wagner (2000)).

In addition, the results yield hypotheses about factors that make negotiated settlements harder or easier to construct that help explain some of the empirical patterns described in section 3. The model suggests that pressure at the center for pro-migration policies makes sons-of-the-soil wars harder to settle by making it clearer to both sides that the government will be under strong pressure to renege on any regional autonomy arrangements in the future.

\section{Data on civil war duration}

One way to approach the question 'What explains variation in the duration of civil wars?' would be to pose hypotheses about factors that might conceivably affect civil war duration (e.g., ethnic heterogeneity, ethnic versus ideological war, per capita income); next compile a list of civil wars and their durations; and then use duration analysis to see if the hypothesized factors correlate with duration as expected.

Casual inspection of typical lists of 'civil wars' shows that they form an extremely heterogeneous lot, however. The 128 conflicts that meet the criteria for 'civil war' discussed below include, for example, 1789-style social revolutions (e.g., Iran 1978, Nicaragua 1979); bloody coups and the violent shuffling of juntas (Argentina 1955, Iraq 1959); big 'classical' civil wars in which relatively well-defined and well-armed adversaries vie for control of a recognized central state apparatus (China 1945, Angola 1975, Afghanistan 1978); many secessionist wars, some big and destructive (Nigeria 1967 or Ethiopia 1974), others highly persistent but so small as to verge on 'banditry' (India 1952, some cases in Burma); some 'ethnic' wars (Sri Lanka 1983), some 'ideological' civil wars (El Salvador 1979), and some anticolonial wars (France/Algeria 1954). ${ }^{3}$

Rather than just start throwing independent variables at such a diverse list, I decided to proceed inductively, sorting the cases by duration and looking for striking patterns. In the next section, I report the results of this inductive effort. ${ }^{4}$ The remainder of this section introduces the data set and discusses the question of what 'civil war duration' means.

\footnotetext{
${ }^{3}$ The list of conflicts may be accessed, along with the replication data, at http://www. stanford.edu/group/ethnic/.

${ }^{4}$ In retrospect, I should have randomly set aside one third or one half of the cases to use to 'cross-validate' the results of the effort to induce patterns in the cases kept for examination. By providing the possibility of an out-of-sample test, cross-validation provides a more principled way of doing induction.
} 
The civil war list analyzed below has 128 cases occurring between 1945 and 1999 that satisfy the following primary criteria. ${ }^{5}$ (1) They involved fighting between agents of (or claimants to) a state and organized, non-state groups who sought either to take control of a government, take power in a region, or use violence to change government policies. (2) The conflict killed at least 1000 over its course, with a yearly average of at least 100. (3) At least 100 were killed on both sides (including civilians attacked by rebels). The last condition is intended to rule out massacres where there is no organized or effective opposition.

Though they differ slightly in their details, these criteria are similar to those employed by most other researchers who have compiled civil war lists (Singer and Small 1994, IISS 2000, Licklider 1995, Sivard 1996, Doyle and Sambanis 2000, Esty et al. 1998, Gleditsch et al. 2001, Valentino 2002). ${ }^{6}$ Note, however, that by themselves these standard criteria are inadequate for identifying the start and end dates of a civil war, which is what we need in order to study determinants of duration.

Naively, we would like to say that a civil war begins when the killing begins and ends when the killing ends. For most cases, start and end years are readily coded using this simple rule. But problems arise for others. If the killing stops and then restarts after a period of time, how long does the period have to be to say that the first sequence represented a completed 'civil war'? How low does the amount of killing have to fall to say the war is over? If the killing begins very gradually and sporadically, exactly when does the war 'start'?

Inspection of various civil war lists (including the list used here) suggests that researchers have handled these questions inconsistently, even if they sometimes specify an arbitrary period like two or five years. The problem is that for a great many conflicts we lack annual figures for numbers killed, so that in a case like the Muslim insurgency in the Southern Philippines it is quite difficult to say whether two or even five years may have passed in the 1980s during which killing remained at very low levels. Given this lack, it seems that the standard civil war lists often rely implicitly on the presence of a formal peace agreement or truce to indicate the end year of many conflicts. That is, a formal agreement or truce followed by a significant reduction in killing that lasts for some period of time (two or five years) is considered a war end.

This is a defensible rule, since surely a peace agreement that results in a major reduction in killing for a sufficient length of time is enough for most people to say that a civil war has ended. But it leaves open the question of what to do about cases like the Southern Philippines

\footnotetext{
${ }^{5}$ The list used for this article is based on that used for Fearon and Laitin (2003), and employs the same criteria; a few cases have been dropped or added according to the results of additional research.

${ }^{6}$ One significant difference is that whereas most others do not code anticolonial wars such as France in Algeria or Portugal in Angola at all, we code them as civil wars under the jurisdiction of the metropole. See the discussion below.
} 
or the very long-running rebellions in North East India. In these, periods of several years may pass with little killing, but no peace treaty or official cease fire. Beyond the problem of lacking data, there is a conceptual question: has a civil war ended if one or both sides take a breather to recoup strength, preparing for new campaigns? Most would probably say that it depends on how strong is the intention to renew violence and how long the breather is intended to last. So for at least some cases the question of deciding when and whether a civil war has ended will be eternally contestable.

Similar problems arise in deciding on the start date of a civil war. Did the Somali civil war begin in 1981 when armed bands of Isaaqs started small-scale operations against Siad Barre's regime and Isaaq collaborators, or in 1988 when Barre razed the Isaaq town of Hargeisa (killing thousands), or in 1991 when Barre's government collapsed and anarchic interclan warfare took over? Here the question is not spells of 'peace' but what to consider a continuous sequence of events that belong to one war. My inclination is to separate this into two wars, one against the Barre regime, and the second among allies in the first war for the control of Mogadishu. In this regard the case parallels Afghanistan, where most lists code two distinct wars, the first beginning in 1978 against the Soviet-supported government in Kabul and the second in 1991 among the victorious allies for control of Kabul. The additional criterion is: (4) If one of the main parties in the conflict was defeated or otherwise drops out, we code a new war start if the fighting continues (e.g., Somalia gets a new civil war after Siad Barre is defeated in 1991).

In the end, any parsimonious rule will generate some start and end date codings that are debatable. Probably the best course is to flag problematic codings and check to see if results are robust to changing them. In addition to (4) above, the rules for coding start and end that I have tried to follow for this case list are: (5) The start year is the first year in which 100 were killed or in which a violent event occurred that was followed by a sequence of actions that came to satisfy the primary criteria. (6) War ends are coded by observation of either a military victory, wholesale demobilization, truce or peace agreement followed at least two years of peace. ${ }^{7}$

\footnotetext{
${ }^{7}$ Three additional criteria are needed for two other issues that arise in a few cases: (7) Involvement by foreign troops does not disqualify a case as a civil war for us, provided that the other criteria are satisfied. (8) We code multiple wars within a country when distinct rebel groups with distinct objectives are fighting a coherent central state on distinct fronts with little or no explicit coordination. (9) If a state seeks to incorporate and govern territory that is not a recognized state, we consider it a 'civil war' only if the fighting continues after the state begins to govern the territory (thus, Indonesia/East Timor 1975, yes, India/Hyderabad 1947, no).
} 


\section{Empirical patterns}

Using these coding criteria, the simple median and mean civil war durations are 5.5 and 8.8 years respectively. But these are misleading numbers, since so many cases in the sample are ongoing wars (25). Dropping them before computing the mean and median would not be a good solution, because the six longest wars in the whole period are coded as ongoing. A better approach is to fit a Weibull distribution to the data (including the censored observations and without covariates), and then use the estimated parameters to produce estimates of median and mean duration. This yields estimates of 7.1 and 11.1 years for median and mean civil war duration, respectively. The top left graph in Figure 2 shows the proportion of civil wars ongoing by year (using the nonparametric Kaplan-Meier estimate). ${ }^{8}$

\subsection{Coups and popular revolutions make for short civil wars}

A number of the civil wars consist of violence during or after coup attempts or popular revolutions in capitol cities. For example, five of the less-than-one-year cases refer to the bloody aftermaths or onsets of coups in Latin America during the early Cold War (Argentina 1955, Costa Rica 1948, Bolivia 1952, Dominican Republic 1965, and Paraguay 1947). There are similar cases outside of Latin America (e.g., Iraq 1959, Yemen Arab Republic 1948). Several other brief civil conflicts refer to popular revolutions involving mass uprisings and demonstrations in the capitol city in support of efforts to unseat a dictatorial regime (Cuba 1958, Iran 1978, and Nicaragua 1978).

So let's define a coup-related civil war as a civil war between groups that aim to take control of a state, and that are led by individuals who were recently members of the state's central government, including the armed forces. Likewise, define for our purposes a popular revolution as a civil war that, at its outset, involved mass demonstrations in the capitol city in favor of deposing the regime in power. ${ }^{9}$

\footnotetext{
${ }^{8}$ Some technical points: (a) The log of the cumulative (empirical) hazard function is almost perfectly linear in the log of duration, which suggests that the Weibull is appropriate. (b) Even so, note that the nonparametric Kaplan-Meier estimates of median duration (which can be read from graphs in Figure 2) tend to be a bit shorter than the Weibull-based estimates. (c) The Weibull distribution fitted to the data without covariates indicates that civil wars become slightly less likely to end with each passing year. This reverses when we control for explanatory factors, below. (d) I also used a simulation-based approach to estimate means and medians from the Weibull models below (Tomz, Wittenberg and King 1999), but the results are nearly identical so for ease of replication I report the estimates based on the maximum-likelihood parameters.

${ }^{9}$ Note that the definition does not pick out all civil wars whose origins are in some way related to a coup d'etat. For instance, the El Salvadoran war in 1979 is coded as beginning with a right-wing coup that mobilizes the government against insurgents and vice-versa, but this is not a 'coup' case by this definition
} 
A rough coding by these criteria yields 22 cases that are either coup-related (19) or popular revolutions (3). The median war duration for these cases is just 2.1 years, with the mean at three years. By contrast, estimated median and mean duration for the noncoup-related and non-revolutionary wars are 9.0 and 12.9, respectively. These are substantively large differences, as further illustrated in Figure 2, which plots the survival curves for coup/revolution cases versus the others. There is a marked difference in lethality, as well. Among completed wars, the median number killed in coup-related and revolutionary civil wars is 4,000, compared to 29,000 for the rest.

\subsection{Post-1991 civil wars in Eastern Europe tended to be brief}

When the civil wars in our list are sorted by region, the Eastern European cases, all but four of which follow and are related to the fall of communism, stand out for being relatively brief. This is confirmed by the relevant survival plot in Figure 2 and by Table I, which shows Weibull-based estimates for civil war duration by region. The average duration of the thirteen Soviet, post-Soviet and Eastern European cases was shorter than the median duration for any other region. The difference proves statistically significant in a multivariate model, as shown below. This cannot be said for any other region except possibly Asia, where civil wars seem to last somewhat longer on average (more on which below).

\subsection{Anticolonial wars tended to be relatively brief}

Wars against with the formal colonial empires, such as that in French Algeria or the Mau Mau rebellion in Kenya, clearly satisfy the definition of civil war used above, which as noted is quite standard. Nonetheless, lists of civil wars exclude such cases, mark them off from civil wars proper, or assign them to (say) 'Algeria' rather than France even though Algeria was a department of France in the 1950s. ${ }^{10}$

Perhaps the rationale is that a civil war is a war between parties within a single state, and the colonial regimes were not proper states. We know this because the colonial territories were separated from the metropoles by water, and these were wars of 'national liberation' that succeeded in setting up independent countries.

But this is an ex post assessment of what is a proper state. We can't make the definition of 'civil war' depend on whether secession is successful or on territorial contiguity. If

because it does not have the leaders of the fighting parties on both sides as members of the government.

${ }^{10}$ Exclude: Licklider (1995), Esty et al. 2000, Doyle and Sambanis (2000). Mark off: Singer and Small (1994). Treat as if independent states: Sivard (1996), Collier and Hoeffler (2002), Gurr (1996). 
Chechnya succeeds in gaining independence from the Russian Federation, should we change our coding so that the fighting in Chechnya in the 1990s is no longer a civil war but an anticolonial war, or a war of national liberation, or some other category distinct from civil war? Was the war over East Pakistan in 1971 not a civil war because pre-1971 Pakistan was not really a 'state' for lack of territorial contiguity?

Certainly the anticolonial wars in the 50s and 60s are distinct in many respects from the other cases in our list. But they meet commonly applied criteria for civil war-hood and may contain useful information. For example, their average duration was shorter than that for other cases. The median and mean duration of the 13 anticolonial wars in the sample are 4.7 and 7.3 years, respectively, as compared to 7.6 and 11.7 for the rest of the cases (estimated). Figure 2 shows the difference in the survival curves.

Perhaps the duration of the anticolonial wars was limited by the great distances at which the colonial powers had to fight, for two reasons. First, it is materially costly to carry a war effort far across the ocean. Second, the widely shared norm holding that a proper state is territorially contiguous might cut against a government's efforts to gain domestic and international support for such a war. If these reasons help explain the relative brevity of the anticolonial wars, then we should find similar results for other civil wars involving noncontiguous territories in the sample. I coded a variable marking whether the rebel group operated primarily on land separated from the land mass of the capitol city by at least 200 kilometers of water or by international boundaries (e.g., East Pakistan). There are nine such cases (five involving Indonesia) in addition to the 13 colonial cases. Together they show no propensity to have shorter durations.

The three classes considered so far - coup-related/revolutionary, post-Soviet collapse, and anticolonial - distinguish civil wars that have been relatively short. We should also ask if the longest civil wars in the data have any striking features in common that differentiate them from the rest of the cases.

\section{4 'Sons of the soil' dynamics may make for longer civil wars}

Civil wars in Asia have lasted longer on average than those in any other region. Quite a few of these display a similar dynamic. The state is dominated and often named for a majority ethnic group whose members face population pressure in their traditional farming areas. As a result, many migrate into less populous and less developed peripheral regions of the country, often with the support of state development projects. The peripheral regions are inhabited by ethnic minorities - the 'sons of the soil' (Weiner 1978) - who sometimes take up arms and support insurgencies against the migrants and the state backing them. ${ }^{11}$ In a

\footnotetext{
${ }^{11}$ For a more detailed discussion of this pattern, see Fearon and Laitin (2000).
} 
variant, the sons of the soil are less concerned with in-migration by the ethnic majority than with the state's monopoly exploitation of fuel or mineral resources in their traditional areas.

The sons-of-the-soil mechanism can be observed in the rebellions by Chakma peoples in the Chittagong Hills of Bangladesh (22 years); Nagas and other 'tribal' peoples in North East India (48 years to 2000); the muslim Moros in the southern Philippines (33 years); Tamils in the North and East of Sri Lanka (17 years to 2000); some of the many peripheral ethnic minorities in Burma that have fought on and off against the Burman-dominated state for at least 50 years; Uighurs in Xinjiang province in China (9 years to 2000); Sindhis against Mohajirs around Karachi in Pakistan (9 years to 2000); Bougainvilleans in Papua New Guinea (10 years, perhaps continuing); and both Achenese (two episodes, the most recent ongoing) and the West Papuans against the Javanese-dominated state in Indonesia (35 years to 2000). Sons-of-the-soil cases appear much less common outside Asia, although they are observed for the Southerners in Sudan (17 years to 2000), rebels in southern Chad (1994 to 1998) and Ethiopia (8 years to 2000), Tuaregs in Mali (just 6 years most recently), and Abkhazis in Georgia (just 3 years).

I have produced a rough-and-ready coding of sons-of-the-soil cases according the following criteria: the civil war involves an insurgent band fighting on behalf of an ethnic minority on the periphery of a state dominated by another ethnic group; against the state's military or paramilitary formations, and/or members of the majority group who have settled as farmers in the minority groups' declared home area; and involves either land conflict with migrants from the dominant group or conflict over profits and control of fuel or mineral resources in the minority's home area. ${ }^{12}$

My research to date suggests that 21 cases meet these criteria, 12 of which are in Asia. The estimated median and mean durations for these sons-of-the-soil cases are 23.2 and 33.7 years, respectively, as compared to 5.8 and 8.5 for the rest of the civil wars. These are large differences! ${ }^{13}$

\subsection{Valuable contraband may make for longer civil wars}

A second factor that may systematically differentiate longer running civil wars is the use by rebel groups of finances from contraband such as cocaine, precious gems, or opium. For rebels to sustain a long-running war, it helps to have a dependable source of finance and weapons. Contraband is not the only possible source - support from foreign states or ethnic

\footnotetext{
${ }^{12}$ Note that an anticolonial war is only a sons-of-the-soil war as well if the metropole sent substantial numbers of settlers to expropriate and farm land in the colony, as in Kenya and Zimbabwe.

${ }^{13}$ The difference between the nonparametric estimates of median duration for 'SoS' and other wars is similarly dramatic: 5 versus 22 years, with $95 \%$ confidence intervals of $[4,7]$ and $[8, \infty]$, respectively.
} 
diasporas are others. But where it can be exploited it is no surprise that it can enable longer civil wars.

Contraband has clearly played a role in several of the longest running civil wars since 1945, such as Colombia (cocaine; 37 years to 2000 as coded here), Angola (diamonds; 25 years to 2000), Burma (opium; off and on for many years, especially in Shan state), and Sierra Leone (diamonds; 9 years to 2000). Reviewing secondary literature on the 128 cases for evidence of major reliance by the rebels on income from production or trafficking in contraband, I coded 17 such cases. The estimated median and mean civil war duration for these 17 cases are 28.1 and 48.2, respectively, as compared to 6.0 and 8.8 for the rest. These high numbers result in part because 10 of the 17 are coded as on-going, and thus are right-censored. ${ }^{14}$

\subsection{A multivariate analysis and some other 'usual suspects'}

Table II, Model 1 displays a multivariate Weibull analysis using the five variables discussed above. ${ }^{15}$ The reported coefficients are the multiple by which the expected war duration is estimated to change when the factor is present. For example, the average duration of a civil war in Eastern Europe is three times shorter, and that of a 'sons of the soil' case more than three times longer, than a case with none of the five attributes.

Since the variables were selected with an eye to their apparent relationship to civil war duration, it is not surprising that the coefficient estimates are both substantively large and 'statistically significant' (excepting noncontiguity). Nonetheless, the multivariate analysis helps us to assess the relative strength of the five bivariate relationships reported above, to check whether the effects factors are independent, and to check whether the five factors explain the apparent impact of more commonly used variables such as ethnic fractionalization.

Table III gives predicted median and mean war durations for a conflict that has just

\footnotetext{
${ }^{14}$ This evidence should be viewed as tentative, since it is obviously hard to estimate the extent of a rebel group's reliance on contraband for revenues. For instance, I do not include the I.R.A. in Northern Ireland or the L.T.T.E. in Sri Lanka, although in each case drug trafficking is sometimes mentioned as a source of rebel finance. It may be that the business synergies between rebel groups and drug traffickers are so strong that any rebel group that can avoid destruction long enough will eventually move into this area.

${ }^{15}$ The results using the Cox proportional hazards approach, which does not assume a particular form for the baseline hazard rate, are close to identical (when compared to the appropriate parameterization of the Weibull model). The estimated coefficients move very slightly towards 1 for all variables. The disadvantage of the Cox method for my purposes is that it does not allow estimates of mean and median duration for different sorts of cases.
} 
one of each of these five factors. ${ }^{16}$ The largest estimated impacts are associated with coup/revolution, Eastern European, and sons-of-the-soil cases, each of which decreases (or increases, for sons of the soil) the expected duration by a factor of more than three. Contraband cases follow, by this metric, with mean durations about 2.6 times longer. Finally, the mean duration of noncontiguous/anticolonial cases is estimated as about $68 \%$ as long as the modal case, though this estimate is not quite significant at the $p=.10$ level. ${ }^{17}$ Note also, from Table II, that after accounting for these factors, the base-line hazard rate is slightly increasing, which means that after conditioning on these five factors, wars are increasingly likely to end with each passing year.

Before trying to explain these findings theoretically, it makes sense to check additional covariates that might be related to civil war duration, and whether they disturb or undermine the results. Given that there is little prior theory in this area, it is not immediately clear what these covariates should be. Still, we can 'round up the usual suspects.'

\subsubsection{Ethnic heterogeneity}

Mainly using data from the Correlates of War civil wars list, some authors have looked for a relationship between ethnic fractionalization and civil war duration, most often on the hypothesis that the relationship should be positive. Collier, Hoeffler and Söderbom (2002) and Eldabawi and Sambanis (2000) found a nonmonotonic relationship in the COW civil war data (from 1960 on), with countries at intermediate levels of ethnic diversity having longer civil wars. Balch-Lindsay and Enterline (1999) find no relationship, though they use a different measure of ethnic fractionalization.

In these data, a bivariate Weibull or Cox regression of duration on ethnic fractionalization shows that ethnic diversity is marginally related to longer civil wars in the full sample, though much more strongly so if the (relatively short) anticolonial wars are dropped. For the full sample, the estimate implies that a civil war in a country with the median level of diversity should be expected to last on average about $47 \%$ longer than one in a country at the tenth percentile. Adding the square of ethnic fractionalization shows no sign of nonmonotonicity. ${ }^{18}$

\footnotetext{
${ }^{16}$ Note that some cases have none of the five attributes (47), some cases have just one (68), some have two (12), and one has three. The most common overlap is between noncontiguity and sons-of-the-soil with six cases coded for both; four cases are coded as both sons-of-the-soil and contraband-financed.

${ }^{17}$ The coefficient estimate for a variable marking only the anticolonial wars is almost identical, although the estimated standard error is slightly larger ( $p=.15$ instead $p=.11$ for noncontiguity).

${ }^{18}$ For the anticolonial wars I estimate the ethnic fractionalization for the whole empire in the year the war starts, using data on ethnic diversity for the former colonies at the time of independence. See Fearon and Laitin (2003) for details. In all cases 'ethnic fractionalization' refers to the often-employed measure based
} 
As shown in Table II (model 2), after controlling for the five factors introduced above, the effect estimate for ethnic fractionalization is even more tenuous. Its coefficient is not significant $(p=.18)$, and corresponds to a substantive effect of a $29 \%$ increase in expected duration when moving from the 10th to the 50th percentile on fractionalization (other variables set to zero). Dropping the 'not contiguous' variable - which mainly marks the relatively short duration anticolonial wars which occured in highly heterogeneous 'states' - weakens the estimate for ethnic diversity considerably more. If we drop the anticolonial cases from the sample, the estimate for ethnic fractionalization is about the same as shown in Model 2. Adding the square of fractionalization again reveals no sign of an inverted 'U.'

Why is there a bivariate correlation between ethnic diversity and war duration, but none apparent in the multivariate analysis? The main 'culprit' is the coup/revolution indicator, which is negatively correlated with ethnic fractionalization. Dropping this from the model restores substantive and statistical significance to ethnic diversity as a predictor of long civil wars. In other words, long-lasting peripheral insurgencies are more common in ethnically diverse countries, whereas more homogeneous countries, especially in Latin America, have been more likely to have the brief civil wars that emerge from coups or revolutions. This may be the pathway, or mechanism, by which ethnic fractionalization associates with longer civil wars.

\subsubsection{Per capita income}

A bivariate Weibull or Cox regression shows per capita income (in the year prior to the war's start) to be negatively associated civil war duration, though the estimate is statistically insignificant. Plotting duration against income reveals an outlier, the 31-year conflict in the richest country in the sample (Britain's Northern Irish 'Troubles'). This case just barely makes the 100 deaths-per-year average required here for inclusion as a 'civil war,' and dropping it yields a much stronger bivariate relationship. The estimated coefficient now implies that going from the 10th percentile on income (403 1985 dollars) to the 90th $(\$ 3,458)$ reduces expected duration by more than a half, from 14.3 to 7.0 years. ${ }^{19}$

on the 1960 Soviet ethnographic atlas. This gives the probability that two randomly selected individuals are from different ethnolinguistic groups. Results are the same if I use the alternative measures of ethnic diversity discussed in Fearon and Laitin (2003).

${ }^{19}$ The main source for the income data is Penn World Tables version 5.6. Where possible, these were extended forward and backwards using growth rate estimates from the World Bank, or estimated using a country-specific time trend and information on per capita energy consumption from COW. Income estimates for the 13 colonial empires in the sample are constructed using the income and population estimates for the former colonies that composed them at the time of independence. This makes for some upward bias in the income estimates for the empires. For details see Fearon and Laitin (2003). 
As seen in Table II (Model 3), per capita income ceases to matter statistically when we control for the other factors. ${ }^{20}$ The bivariate impact of income has been 'picked up' in part by contraband and sons-of-the-soil dynamics, which are more common in poor countries, but mainly by the Eastern Europe dummy, which marks countries that are all in the top third of the sample's income distribution. Possibly, then, higher income helps 'explain' why the Eastern European cases are relatively short. Low income may make for longer wars by favoring contraband financing and sons of the soil rebellions.

\subsubsection{Country population}

Larger countries tend to have somewhat longer civil wars. Using the estimate from a bivariate Weibull regression, a move from the 10th to 90th percentile on population associates with a change from 8.6 to 14.6 years in expected duration. As seen in table II (model 4), however, the log of country population ceases to matter substantively or statistically when we control for the factors discussed above. Larger states, it turns out, have been more prone to sonsof-the-soil dynamics, and have tended not to have coup or revolutionary wars and the short durations associated with them.

\subsubsection{Ethnic wars and secessionist war}

Many researchers have drawn distinctions between 'ethnic' and non-ethnic or 'ideological' civil wars, with some arguing that ethnic wars are harder to resolve (Kaufmann 1996; Licklider 1995; Sambanis 2001). Testing the hypothesis requires that we code ethnic civil wars as distinct from other civil wars, a more problematic task than it first appears. For any given rule, there are ambiguous or hard-to-code cases (e.g., the wars in Guatemala, Mozambique, Sierra Leone). Nevertheless, designating as 'ethnic' conflicts in which the fighting was in the name of or carried out primarily by groups organized along ethnic lines, I created a variable that takes a value of 1 for non-ethnic cases, 2 for cases that are mixed or ambiguous, and 3 for 'ethnic' cases. These form, respectively, $28 \%$ (36), 17\% (21), and $55 \%$ (70) of the sample.

In a bivariate Weibull regression, 'ethnic wars' have lasted somewhat longer on average. Going from 1 to 3 on the variable associates with about a $60 \%$ increase in expected duration, although the coefficient is not significantly different from zero $(p=.12)$. The effect diminishes much more when we control for the other factors, as seen in Table II, model 5. In this case, the factor most responsible for 'killing' the bivariate relationship between ethnic wars and longer duration is sons-of-the-soil dynamics. All sons-of-the-soil wars are 'ethnic,' but not all

\footnotetext{
${ }^{20}$ The British outlier has been dropped in this model.
} 
ethnic wars have sons-of-the-soil dynamics. It appears that the presence of these dynamics rather than ethnic organization of the combatants is the better predictor of long civil war duration. ${ }^{21}$

A related hypothesis holds that wars of secession are more intractable than civil wars in which the parties aim at capturing the center of the state. To assess this I coded a variable that equals 1 for civil wars in which the parties aim at capturing the center, 3 for civil wars where one of the parties fights for secession or greater autonomy, and 2 for cases that are ambiguous or involved both aims at different times. I find that outside of Eastern Europe and controlling for the anticolonial/noncontiguous cases, secessionist and autonomy seeking wars have lasted significantly longer on average than other cases. This relationship evaporates, however, when we control for either coups (which associate with aiming at the center) and the sons-of-the-soil dynamic (which occur exclusively in secessionist/autonomy related wars but is a better predictor of long duration).

\subsubsection{Democracy}

Some argue that political democracy should reduce the likelihood of civil war because democracies enable aggrieved groups to work for redress through institutional means. ${ }^{22}$ The argument might further imply that if a democracy does have a civil war, it should be easier to resolve (Balch-Lindsay and Enterline 1999). Democratic institutions might facilitate bargaining and credible commitments to an agreement. On the other hand, a selection effect might work in the opposite direction. It might be that if a democracy gets a civil war it probably faces an obdurate rebel group, militating against the finding of a bivariate relation between quick settlement and democracy.

As seen in Table II (model 6), in these data a measure of democracy in the year prior to the start year of the conflict bears no systematic relationship with civil war duration, in either a bivariate or a multivariate analysis. ${ }^{23}$

\footnotetext{
${ }^{21}$ The results do not change when I drop the anticolonial wars from the sample, which are coded as here as 'ethnic.'

${ }^{22}$ Fearon and Laitin (2003) find no support for this common claim in analysis of the determinants of civil war onsets and magnitudes (after controlling for per capita income).

${ }^{23}$ The measure is the difference between the Polity IV democracy and autocracy scores, which makes a scale from -10 to 10. 'Interregnums' and 'transitional periods' are treated as suggested by the Polity coders, and civil wars in the colonial empires have been dropped from the sample.
} 


\subsubsection{Costs (lethality)}

One might initially expect more costly civil wars to end more quickly, and indeed the log of average deaths per year is strongly associated with shorter duration in a bivariate Weibull or Cox regression. Expected duration drops from 15.1 to 8.2 years as one moves from the 10th percentile (500 dead per year) to the 90 th (39,000 per year). However, as shown in Table II, Model 7, the effect disappears when we control for the other factors. In this case, the culprit is almost entirely sons-of-the-soil rebellions, which are usually of very low intensity. So one reason that these cases tend to last a long time may be that they involve relatively few combatants, pose relatively little threat to the center, and thus stay fairly small. They are difficult to eliminate entirely, and because they tend to be so small, not worth the cost of doing so.

\section{Explaining the empirical patterns}

Simply observing that civil wars in Eastern Europe have tended to be brief, or that sonsof-soil dynamics associate with longer civil wars, is of course not an explanation. In this section I return to the theoretical questions posed in the introduction, developing answers that show how the diverse empirical patterns described above may be explained by common theoretical principles.

Both coups and peripheral insurgencies (i.e., rural guerrilla warfare) are strategies for using violence to take power. The leaders of would-be coups and popular revolutions hope that a rapid strike or public protest will initiate a tipping process that produces wholesale defections within the regime (especially the military) or mass demonstrations in the capitol that have the same effect. This technology, a tipping process, is basically all or nothing. ${ }^{24}$ Either the coup leaders succeed or they are crushed when the hoped-for tip fails to develop. This is why civil wars that originate in coups or popular revolutions tend to be quite brief.

The strategy of violence in peripheral insurgencies is radically different. Rebel leaders rarely expect to win quickly by means of a tipping process that causes the government to collapse. Instead, peripheral insurgencies are wars, proper, in the sense that the parties hope to prevail in one of two general ways: either by gaining a position of military dominance that allows the imposition of terms, or by using violence to inflict costs that will induce the

\footnotetext{
${ }^{24}$ 'It was a win-big, lose-big gamble for [Senator Juan Ponce] Enrile and company, and it looks like they lost big,' said a Philippine political commentator speaking on Enrile's involvement in mass demonstrations against President Gloria Arroyo that failed to bring the military to the side of Enrile and jailed former President Estrada (Lander 2001). Enrile has now been arrested.
} 
other side to negotiate a favorable settlement. ${ }^{25}$ The longer duration of insurgencies versus coups and revolutions is thus a function of rebel strategy.

Though promising, this argument does not explain why the participants in these violent and risky events can't do better by negotiating a deal with the government, whether in preference to a coup attempt or a peripheral insurgency. Nor does it explain why some peripheral insurgencies last longer than others. The two questions are related. If bargaining is possible, then it is not clear how or why the relative military capabilities of rebels and the government would affect the duration of peripheral insurgencies. Roughly equal capabilities (a 'hurting stalemate') should incline the parties towards deal. Unequal capabilities should lead to a quick loss or to concessions by the weaker side. Put differently, if we have no explanation for why the parties are fighting at all (rather than settling), it is not clear how we can 'explain' variation in war duration.

From a rationalist perspective, there are basically two approaches to explaining what prevents an implicit or explicit deal in preference to a coup attempt or an insurgency. Either some party has private information about the value of the deal (or the military alternative to it) but can't reveal this credibly, or some party can't credibly commit to stick by any deal that both would prefer to a fight. ${ }^{26}$

The literature on coups d'etat often notes that rulers pay militaries with an eye to forestalling coup attempts, thus recognizing the incentives for coup-avoiding deals. But this same literature, so far as I know, does not ask what explains failures of this or other coupavoiding strategies. ${ }^{27}$ By contrast, the dramatic and extended violence of many insurgencies has provoked efforts at explanation, often in 'rationalist' terms. Indeed, a common informal story views insurgencies as wars of attrition driven by private information. Government and rebels use violence as a costly signal of resolve or capability, which is privately known by each side in the contest. The combatants fight rather than settling in order to credibly reveal that they are more determined or stronger than the enemy realizes, and so must be given better terms. The war of attrition is expected to end when the true balance of resolve or capabilities is publicly revealed. ${ }^{28}$

\footnotetext{
${ }^{25}$ This isn't exactly right since, as I show below in the model, one can have a situation where both the rebels and the government fight despite having zero expectation of military victory or a negotiated settlement and despite the presence of deals both sides would prefer to the hopeless war.

${ }^{26}$ These possibilities are not mutually exclusive. See Fearon (1995) for a general discussion.

${ }^{27}$ For example, Galetovic and Sanhueza's (2000) model of coups d'etat does not allow the autocrat to pay off the coup plotter, and does not raise the issue of efficiency.

${ }^{28}$ Blainey (1973) is associated with this view in the literature on interstate wars, although he saw the source of disagreements about odds as irrationality rather than private information. Attempts at more rationalist versions have been advanced by Goemans (2000) and Wagner (2000).
} 
This story about insurgencies is supported by much anecdotal evidence and seems intuitively plausible, at least regarding the early phases of such conflicts. ${ }^{29}$ One might also propose a private-information-based explanation for why coups occur. For example, perhaps the possibility of ex ante bargaining is undermined by coup plotters' inability to credibly reveal private information about the likelihood of a 'tip'? Nonetheless, while I do not discount this mechanism, a private-information-based story runs into significant obstacles for both coups and insurgencies.

For peripheral insurgencies, it strains credulity to imagine that the parties to a war that has been going on for many years, and that looks very much the same from year to year, can hold any significant private information about their capabilities or resolve. Rather, after a few years of war, fighters on both sides of an insurgency typically develop accurate understandings of the other side's capabilities, tactics, and resolve. Certainly both sides in Sri Lanka (for instance) fight on in the hope that by luck and effort they will prevail militarily. But it is hard to imagine that they do so because they have some private information that makes it reasonable for them to be more optimistic about the odds than the other side is. In the absence of significant private information, why can't they cut a deal on the basis of a more-or-less common understanding of the terms of the military stalemate?

Below, I present a game-theoretic argument that can explain the inefficient occurence of both both coup attempts and peripheral insurgencies as a result of a commitment problem. The main idea is that a temporary shock to government capabilities or legitimacy gives coup plotters or rebels a window of opportunity. During such moments the ruler might want to commit to paying the junior officers more, or giving more autonomy to a region, but such commitments are rendered incredible by the knowledge that the shock is temporary.

The model shows how a commitment problem could prevent an insurgency from being ended in any way except by a military defeat. This is so despite the ability of the parties to bargain over the extent of regional autonomy by a regional leadership/rebels, and the absence of private information about military capabilities or resolve. In the model's equilibrium, both government and rebels may fight on, year after year, with but a slim hope that luck and effort will put them in a position to impose terms militarily, and despite the presence of bargains that both sides would prefer to the situation of constant war. The problem is that bargains are unenforceable due to fluctuations in the government's capabilities. ${ }^{30}$

\footnotetext{
${ }^{29}$ For example, Hamas explained its strategy in December 2001 as follows: 'The enemy will not recognize our people's right in his land unless forced to. The suicide operations come as part of the war of attrition waged by our people and in response to the killing of children and the assassination of leaders' (MacFarquhar 2001).

${ }^{30}$ The model is related to that of Acemoglu and Robinson (2001), who try to explain democracy as commitment strategy by elites. It can also be viewed as a stochastic-game version of Fearon $(1994,1998)$, who showed how civil wars could begin when a minority group anticipates a shift in military power towards the state, which would make promises by the center to construct and maintain regional autonomy or other
} 
Regarding the duration of peripheral insurgencies, the model suggests hypotheses about the circumstances in which it is easier or harder to construct a stable settlement.

\section{Secessionist war as a commitment problem}

To save space I describe the extensive form for the model applied to peripheral insurgencies where the goal is secession or greater regional autonomy. Minor modifications of the extensive form and payoffs make it a model of the coup problem or a rebellion aimed at the center; these are mentioned in footnotes.

\subsection{The game form}

Two players, a central government $G$ and a rebel group (or the leadership of the rebel group) $R$ interact in successive periods $t=0,1,2,3, \ldots$. We will speak of two kinds of periods, war periods during which the parties are fighting, and peace periods when they are not. The extensive forms for the two stage games are illustrated in Figure 3.

A peace period begins with Nature choosing whether the government is in a strong or weak position with respect to potential rebels. This could refer to the government's (and the country's) economic health, or to weakness related to a coup or political in-fighting at the center, for example. Weakness results from some kind of economic or political shock to government capabilities, such as a sharp economic downturn, the cessation of foreign military or development aid, or a political collapse at the center (e.g., the collapse of communist regimes or the death of a dictator). The government starts a peace period strong with probability $1-\epsilon$ and is weak with probability $\epsilon \in(0,1)$.

In either event, after Nature's move the government chooses how to share control of a region of the country between itself and regional political elites (who are also the potential rebels). The government chooses a share $c_{t} \in[0,1]$ that indicates how much control of regional tax revenues and other political matters that it retains for itself. For instance, $c_{t}=1$ means that the center assumes full control; $c_{t}=.5$ indicates an agreement on regional

measures incredible. Walter (1997) argues that the central obstacle to ending civil wars by negotiation is that mutual disarmament by government and rebel forces is a Prisoners' Dilemma in which neither can tolerate any risk of being 'suckered.' Although it is not clear why thorough-going disarmament is a necessary condition for ending a civil war (why not an agreement where the rebels keep their guns but agree not to use them?), there are many cases where such provisions were included in peace settlements and did pose major obstacles to implementation. See also Fearon (1995, 404-409) and Powell (2003), who formulates and analyzes the underlying strategic mechanism in these papers in more general terms. 
autonomy that shares control 50-50 between the center and regional powers.

If the government is in a strong position, then following the government's choice of $c_{t}$, the game simply proceeds to the next period, which is again a peace period. However, if the government has suffered some political or economic shock and is in a weak position, then the rebels have the opportunity to initiate a civil war. If they choose not to start a fight, the game moves to the next period, which is again a peace period. If the rebels choose to begin a war, a war period follows.

At the start of a war period, Nature decides whether the fighting results in the rebels achieving a position of military dominance, which has probability $\alpha \in[0,1]$; the government gains military dominance, with probability $\beta \in[0,1]$; or neither does, with probability $\gamma \in[0,1](\alpha+\beta+\gamma=1)$. If the rebels achieve military dominance in a period, I assume that this means that they can set up a de facto autonomous region and the game ends. If the government achieves military dominance, the game continues, but the next period is a peace period. If a stalemate obtains, then the government and the rebels choose in sequence whether to continue their fight. If the government stops fighting, then the rebels can set up a de facto autonomous region and the game ends. If the rebels stop fighting, the game continues with the next period as a peace period. If both continue fighting, the next period is a war period. ${ }^{31}$

\subsection{Preferences}

Assume that each side prefers more control of the region to less, and for convenience suppose that these payoffs are linear in $c_{t}$, the government's share of control in a peace period $t$. Thus in a peace period payoffs are $c_{t}$ for the government and $1-c_{t}$ for the rebels/regional leadership if the government chooses $c_{t}$. During a war period, let the government's payoff be $k_{G}$ and the rebel's $k_{R}$. These incorporate whatever benefits each side can obtain from the region while fighting (such as war taxation imposed by the rebels or plunder by government forces) minus the costs they incur from the war effort. I allow for the possibility that $k_{G}>0$, which means that the government prefers the net benefits it can obtain while fighting to letting the region go entirely. Likewise, I allow that $k_{R}$ can be greater than zero, which means that the rebel leaders can do better day-to-day during war than they could if they were shut out of regional control $(c=1)$ during peace. However, I assume that $k_{G}+k_{R}<1$, which ensures that there are always regional autonomy deals on $c \in[0,1]$ such that both sides prefer these to continued fighting.

\footnotetext{
${ }^{31}$ In the 'coup' variant, the $R$ is a group of putchists who can choose to strike if the government is weak. In this case either the 'tip' occurs and the rebels assume control of the government in the next period with probability $\alpha$, or it fails and they are killed or jailed with probability $\beta$, where $\alpha+\beta=1$. The losing side in a coup attempt exits the game, and new potential putchists enter in the next period.
} 
If the rebels win, they can set up a de facto autonomous region and the game ends. In this event, the rebels receive their value for full control, 1, in every subsequent period, so their continuation payoff is $\delta /(1-\delta) . \delta \in(0,1)$ is the common discount factor applied to all per-period payoffs. The government, on the other hand, gets 0 in every subsequent period for losing the region, so its payoff here is just $0 .^{32}$

To summarize the model, a government periodically suffers random shocks to its capabilities, at which times dissatisfied regional actors have the opportunity to initiate an insurgency. If they start an insurgency, the war continues until one side quits or one side prevails militarily. When the government is strong, it chooses how much to share control of the region with regional elites. We could easily add an option for the government to make offers on the division of powers during war periods, but as we will see below this is unnecessary, since the whole question for the rebels is whether any such deal would be observed once the government is in a strong position again.

\subsection{Equilibrium results}

So much for the specification of the game. What happens? ${ }^{33}$

Proposition 1. When conditions (1) and (2) below hold, the following strategies call these the Fight Equilibrium - form a subgame perfect equilibrium in the game: In all peace periods, the government does not share any power in the region (i.e., chooses $c_{t}=1$ ), and the rebels always choose to fight if the government is weak. In all war periods, both government and rebels always choose to keep fighting.

The conditions are:

$$
\begin{aligned}
& k_{G} \geq-\beta \delta /(1-(1-\epsilon) \delta) \\
& k_{R} \geq-\alpha \delta /(1-\delta)
\end{aligned}
$$

In this equilibrium, the regional elites (or would-be elites) expect to be shut out of control in the region by the government. In consequence, provided their costs during a fight are not too high relative to the expected benefits of autonomy (condition 2), they want to try their luck at war whenever they have the chance. And if the rebels will fight whenever they have the chance, it makes sense for the government to monopolize control of regional

\footnotetext{
${ }^{32}$ Payoffs are defined naturally for the coup variant; the only new outcome is a failed coup, which yields a 'death' or 'jail' payoff for the loser, say $-K$. Also, $c_{t}$ should now be interpreted as rents distributed to the military by the ruler.

${ }^{33}$ Proofs for the propositions are in Appendix 1.
} 
benefits when they can, by setting $c_{t}$ to 1 . This in turn justifies the regional elite's strategy of always rebelling, so confirming the equilibrium. The condition on $k_{G}$ ensures that the government cares enough about the benefits from controlling the province relative to the costs of fighting that it is willing to fight rather than just cede autonomy (as with much decolonization or the break-up of the Soviet Union).

In the Fight Equilibrium, the expected duration of a civil war once it starts is $1 /(\alpha+\beta)$. Note that this can be very long when neither side has the capabilities to provide a good chance of a decisive military victory ( $\alpha+\beta$ close to zero). Note also that if the rebels can arrogate enough tax and political authority in the region during a war that they do better than they would as non-rebels without a war $\left(k_{R}>0\right)$, then the fight equilibrium can be sustained even if they expect zero chance of prevailing militarily $(\alpha=0)$. Unfortunately, it is also possible to sustain the Fight Equilibrium when the government has zero chance of winning outright, provided that $k_{G}>0$. As shown below in Proposition 3, in this depressing case the parties can be locked in a completely unwinnable war despite the presence of mutually preferable deals on sharing control of the region.

Proposition 2. The Fight Equilibrium is inefficient - there is always a set of possible deals $C \subset[0,1]$ on regional autonomy such that both sides would prefer to have any $c \in C$ chosen by the government in every period over the Fight Equilibrium.

Even if rebel and government military leaders can 'make out like bandits' in a civil war ( $k_{R}$ and $k_{G}$ greater than zero), the fact that the conflict is destructive of life, property, and economic activity imply that they could do even better with an appropriately distributed settlement. ${ }^{34}$

Proposition 3 establishes, however, that under certain conditions it is impossible to construct a peaceful subgame perfect equilibrium that attains such a distribution. ${ }^{35}$

Proposition 3. Suppose that conditions 1 and 2 above hold. Let $V_{G}^{P}$ be the government's value for the Fight Equilibrium starting from a period in which it is strong, and $V_{R}^{W}$ be the rebels' value for the Fight Equilibrium starting from a period in which the government is weak. Then when $\delta V_{G}^{P}+V_{R}^{W}>1 /(1-\delta)$ there does not exist a subgame perfect equilibrium in which peace prevails on the equilibrium

\footnotetext{
${ }^{34}$ In fact, a stronger version of Proposition 2 is true: Any equilibrium of the game in which fighting occurs with positive probability is inefficient, since both players could be made better off by replacing a 'fight' period with a peace period in which all the gains of regional control are divided up.

${ }^{35}$ An earlier version of this paper had a slightly less general result for Proposition 3 . I am grateful to Robert Powell for pointing out how it could be improved. See Powell (2003) for an analysis of the underlying logic as it applies in several political settings.
} 
path. When this inequality does not hold, there exist subgame perfect equilibria in which government and region share power in the region and do not fight on the equilibrium path.

The problem is credible commitment. When the government is weak, it would like to commit to a regional autonomy deal in preference to a long civil war. Regional elites anticipate, however, that once the government has regained its strength, nothing stops it from overturning or undermining the arrangements. When the government expects that it can maintain its position for sufficiently long when its capabilities are strong (i.e., $\epsilon$ is small enough relative to $\delta$ ), the distant future threat of more rebellion by the region is not sufficient to keep it to a bargain.

Before presenting comparative statics results, I give a final Proposition that concerns cases where the two conditions necessary to sustain a Fight Equilibrium (1 and 2 above) do not both obtain. To recall, condition (2) says that the rebels prefer to fight on in the hope of military victory (or war-time tax and other benefits) if the government is expected always to oppress (set $c_{t}=1$ ). Condition (1) implies that the government prefers to fight in hopes of reimposing its rule rather than just ceding autonomy. If (1) is not satisfied, then the government's incentive to let the region go is greater, as is the rebels' incentive simply to live with zero regional control if (2) is not satisfied. Proposition 4 provides sufficient conditions for these to be unique equilibrium outcomes.

Proposition 4. (a) If (1) holds and $k_{R}<-\delta(\alpha+\beta) /(1-\delta)$ then then the game's unique subgame perfect equilbrium has the government choosing $c_{t}=1$ and to fight if given the choice, while the rebels choose not to fight whenever they can. Thus, on the equilibrium path, the government assumes full control of the region and this is not contested by rebels when the government weakens.

(b) If $(2)$ holds and $k_{G}<-\beta \delta /(1-\delta)$, then the game's unique subgame perfect equilibrium has the rebels fighting whenever they can, the government choosing $c=1$ whenever it can, and the government ceding autonomy whenever it has this choice. Thus, on the equilibrium path, the government assumes full control until it faces a shock, in which period it allows full autonomy.

\subsection{Comparative statics results}

Changes in the model's parameters can affect the likely duration of a conflict in two ways: directly, by affecting the probability of stalemate during fighting $(\gamma)$, or indirectly, by affecting the difference between the minimum deals that each side is willing to live with in

preference to the Fight Equilibrium. Strictly speaking, in the model this difference bears 
only on the probability that civil war occurs, not on its duration. For a given set of parameters, either there are stable regional autonomy deals or not, and, if not, expected war duration is just $1 /(1-\gamma)$. It may be reasonable to assume, however, that the smaller the difference between each side's minimum for an enforceable peace deal, the more likely that random, unanticipated shocks to parameters that occur in the course of a conflict will render a deal feasible ('open up a bargaining space'). I make this assumption in interpreting the comparative statics of the model. ${ }^{36}$

\subsubsection{Benefits obtained and costs incurred during a civil war}

Increasing the benefits that government or rebel leaders can obtain during a civil war $\left(k_{G}\right.$ and $k_{R}$ ) lowers the likelihood that a stable regional autonomy agreement can be reached. ${ }^{37}$ Increasing the government's benefits for unopposed control of the region, or the rebels' benefits for full autonomy, has the same effect (formally this is equivalent to increasing $k_{G}$ or $\left.k_{R}\right)$.

The logic behind this conclusion is not that the parties have less incentive to agree when they are doing relatively well in war. In this model, the parties always have an incentive to agree since they could always do better with some autonomy sharing arrangement. Rather, the logic is that when (say) the rebels do better day-to-day in a civil war (due to contraband or outside support, for instance), they need to be given more in a regional autonomy deal to be willing to accept it. But the more the government has to give away, the more tempted it will be to renege when it is again in a strong position, which makes it harder to construct a credible negotiated settlement.

This result may help explain why sons-of-the-soil and contraband-financed insurgencies are so intractable. When the state is controlled by a majority ethnic group whose members include large numbers of impoverished, land-poor farmers, the government has an enduring interest in favoring migration to less populated peripheral areas. Even if the center has incentives to cut regional autonomy deals to reduce costly fighting with minority guerrillas, both sides know that the center will soon face strong political pressures to renege on behalf of migrants. Likewise, if significant natural resource or contraband rents are available in the region, this increases $k_{G}$ or $k_{R}$ (whoever controls them), thus making a negotiated settlement more difficult to construct.

This result may also inform the finding that anticolonial wars were somewhat brief.

\footnotetext{
${ }^{36}$ See Fearon (2003) for mathematical details on the comparative statics results.

${ }^{37}$ That is, increasing $k_{G}$ or $k_{R}$ shrinks the set of enforceable autonomy agreements as given by Proposition 3 , so that the ex ante probability of a stable deal decreases on the argument that this is what would occur if all other parameters were drawn from probability distributions before the start of the game.
} 
Note first that Britain and France let the large majority of their colonies go without any fight at all. And not for lack of military capability and prospects - the British successfully crushed the Mau Mau insurgency in Kenya in the space of a few years, and in only a few cases did the British or French face armed colonial insurrections. In the terms of the model, most of decolonization corresponds to the second case described in Proposition 4, where an exogenous shock (the end of World War II and the change in great power leadership to states opposed to colonialism) confronted metropoles that simply were not willing to bear many costs to keep their empires $\left(k_{G}\right.$ was significantly negative). The main exceptions are just those cases where the metropole had strong economic or domestic political benefits (due to lobbying by settlers) for keeping control, namely French Algeria and Angola, Guinea Bissau, and Mozambique for Portugal. ${ }^{38}$

\subsubsection{Military capabilities}

Empirical studies of both civil and interstate war duration often look for an effect of 'relative capabilities,' usually on the hypothesis that balanced capabilities should imply longer duration. $^{39}$ The mere set-up of the model shows that it is too simplistic to think in terms of a one-dimensional 'balance of capabilities' when asking about war duration. Military capabilities influence the odds of one side winning decisively $(\alpha / \beta)$ and the probability of stalemate $(\gamma)$. For example, 'relative capabilities' in the sense of $\alpha / \beta$ might be the same for (a) coup plotters vs. a government, and (b) rural guerrillas vs. a government, but the odds of stalemate are radically different $(\gamma=0$ in (a), $\gamma$ close to 1 in (b)). It is not the balance of capabilities that directly affects duration here, but their nature $(\gamma)$. To complicate matters further, the 'balance of capabilities' could influence duration by affecting the ability to construct a regional autonomy deal.

In the model, making the military technology less decisive without changing relative capabilities (i.e., increasing $\gamma$ holding $\alpha / \beta$ constant) directly increases average war duration by making an outright military victory less likely in any given period. However, making the military technology less decisive also influences prospects for a regional autonomy deal. Unfortunately, the exact nature of the influence depends on specific parameter values. For instance, if both rebels and government find fighting quite costly $\left(k_{G}\right.$ and $k_{R}$ both less

\footnotetext{
${ }^{38}$ On the economic importance of the 'ultramar' to Salazar's Portugal, see Cann (1997).

${ }^{39}$ Bennett and Stam (1996) found that balanced national capabilities were powerfully associated with longer interstate wars. The hypothesis is difficult to apply to civil wars, since it is meaningless without a common metric by which to compare capabilities. How to assess whether a state's military capabilities are 'balanced' with those of a band of guerrillas, except by looking at the results that we want to predict? Balch-Lindsay and Enterline (1999) find that third party interventions on both sides in a civil war associate with longer duration in the COW civil war data set, although without a common metric we can't say whether these interventions made the 'balance of capabilities' more balanced or less balanced.
} 
than 0), then making military conflict less decisive makes them more able to cut a stable autonomy deal. By contrast, when either or both - but especially the rebels - prefer fighting to being completely shut out of regional control $\left(k_{G}>0\right.$ or $\left.k_{R}>0\right)$, then it is possible for less decisive military technology to actually make it harder to reach a negotiated settlement. The intuition is that when the day-to-day benefits of fighting are relatively good, more stalemate-prone technologies improve the rebel group's payoff for fighting versus being 'shut out.' This implies that the government must give up more in a peaceful settlement, which in turn makes the government's commitment problem harder to solve. ${ }^{40}$

Regarding relative capabilities, it is roughly correct to say that in this model, improvements in the rebels' ability to win decisively work against negotiated settlements, whereas increases in government strength tend to favor them. The typical logic is that increases in $\alpha$, the rebel's per period probability of decisive victory, directly increase the minimum the rebels have to be (credibly) offered in a period when the government is weak in order to prefer peace. Even though increasing $\alpha$ lowers the government's value for war and so tends to make it more receptive to compromise, this effect is 'discounted' when the government is strong (and deciding whether to stick to a peace deal) by the improbability of its becoming weak again soon. ${ }^{41}$

More specifically, it is possible to show that if we increase the rebels' capability to win decisively (i.e., increase $\alpha$ holding $\beta$ constant, letting $\gamma$ decrease), this always decreases the probability that a negotiated settlement can be constructed. Similarly, if we increase the rebels' relative odds of decisive victory without changing 'decisiveness' (increase $\alpha / \beta$ holding $\gamma$ constant), the prospects for a stable regional autonomy deal drop. However, the effect of increasing the government's chance at decisive victory at the expense of the probability of stalemate depends in a complicated way on the value of other parameters.

The results argue against there being any very definite relationship between 'relative capabilities' and the expected duration of civil wars. They do suggest that an advantage in, or positive shocks to, rebel capabilities will tend to reduce the odds of a negotiated settlement.

\section{Conclusion}

The results and arguments of the last section help explain four of the five principal empirical findings from the first part of the paper. Wars originating as coups or popular revolutions

\footnotetext{
${ }^{40}$ See Fearon (2003) for the formal condition.

${ }^{41}$ Quite possibly the reverse result would obtain if we assumed that random shocks influence the capabilities of a regional political authority set up by an autonomy deal.
} 
have tended to be short because this 'technology' for taking state power turns on the success or failure of a rapid tipping process - hoped for defections within the security apparatus. Peripheral insurgencies, by contrast, succeed or fail either by military victory or by gaining a favorable negotiated settlement. ${ }^{42}$

Civil wars since 1945 have lasted significantly longer when they have involved land or natural resource conflicts between state-supported migrants from a dominant ethnic group and the ethnically distinct 'sons of the soil' who inhabit the region in question. They also last longer when the rebels have access to finance from contraband goods like opium or cocaine. The model's results showed that a stable regional autonomy deal is harder to construct when the political center's stakes in the region are greater, as when land is wanted for migration of members of the ethnic minority or the region has valuable natural resources. Similarly, a negotiated settlement is more problematic when the rebel force can extract more from a region during the course of a war, say by 'taxation' or drug trafficking. Both factors make deals harder to reach by requiring that one side get more to prefer peace to war, which implies that suspicions about reneging are more justified.

Finally, anticolonial wars tended to be few relative to the numbers of colonies and somewhat shorter than average in this period. In the model, a political center that faces large costs for fighting relative to the benefits of holding a territory will hold on till faced with an exogenous shock, and then 'let go' without a fight. If the costs are just low enough to incline it to fight, a negotiated settlement would be expected to be relatively easy to reach.

Empirically, the several civil wars in post-Soviet Eastern Europe have been relatively short. These cases appear to have been shorter because the rebels in most of them had support from a strong power against quite weak and new states, allowing for fairly decisive rebel victories at an early stage. In the model, increasing one side's probability of decisive victory shortens expected war duration. However, the thrust of the analytical results on relative military capabilities is that matters are complicated, since imbalanced capabilities tend to reduce prospects for a negotiated settlement while balanced capabilities increase them. The empirical obstacles to testing the impact of relative capabilities on civil war duration are also great, since governments and guerrillas deploy such different capabilities that it is difficult to know how to measure the balance. In addition, the model highlights the problem of untangling relative capabilities from the propensity of different capabilities to produce decisive victory or stalemate.

The idea that commitment problems are important obstacles to reaching stable regional autonomy deals is advanced here as a theoretical conjecture that has implications consistent

\footnotetext{
${ }^{42}$ Alternatively, as shown by an interesting case in the model, they may 'succeed' by providing the rebels and government agents an income and other benefits that is better than what they could get under a peace deal, due to commitment problems that destabilize mutually advantageous settlements.
} 
with the empirical record. ${ }^{43}$ Future research might profitably investigate whether or how this mechanism matters in particular cases. Policy analysts concerned with civil war termination might focus more on strategies of international monitoring that allow mutually advantageous commitments to be made. Another simple, general point that emerges from the analysis is that the mechanisms driving civil wars differ markedly. We can gain a lot of empirical and theoretical leverage by looking looking for these distinct mechanisms before we start running regressions. For example, apart from Weiner (1978) and Fearon and Laitin (2000), 'sons of the soils' cases have not been noticed in the civil conflict literature as having quite distinct and interesting (if tragic) dynamics.

\footnotetext{
${ }^{43}$ The model developed in section five focuses the question of credible commitment by the government. However, governments also worry that granting a regional autonomy deal may empower regional radicals to demand even more. So there are potential problems of credible commitment on both sides worth exploring more systematically in future work.
} 


\section{Appendix}

Proof of Proposition 1. Call the Fight Equilibrium strategies $\sigma^{F E}=\left(\sigma_{G}^{F E}, \sigma_{R}^{F E}\right)$. Under $\sigma^{F E}$, $G$ 's expected payoffs are given by

$$
\begin{aligned}
V_{G}^{P} & =(1-\epsilon)\left(1+\delta V_{G}^{P}\right)+\epsilon\left(1+\delta V_{G}^{W}\right) \\
V_{G}^{W} & =k_{G}+\alpha 0+\beta \delta V_{G}^{P}+\gamma \delta V_{G}^{W}
\end{aligned}
$$

where $V_{G}^{P}$ is $G$ 's expected payoff going into a peace period and $V_{G}^{W}$ is $G$ 's expected payoff going into a war period.

Similarly, $R$ 's expected payoffs in $\sigma^{F E}$ are determined by

$$
\begin{aligned}
V_{R}^{P} & =(1-\epsilon)\left(0+\delta V_{R}^{P}\right)+\epsilon\left(0+\delta V_{R}^{W}\right) \\
V_{R}^{W} & =k_{R}+\alpha \delta \frac{1}{1-\delta}+\beta \delta V_{R}^{P}+\gamma \delta V_{R}^{W}
\end{aligned}
$$

These solve, tediously, to

$$
\begin{aligned}
V_{G}^{P} & =\frac{1-\gamma \delta+\epsilon \delta k_{G}}{(1-(1-\epsilon) \delta)(1-\gamma \delta)-\beta \epsilon \delta^{2}} \\
V_{G}^{W} & =\frac{k_{G}}{1-\gamma \delta}+\frac{\beta \delta}{1-\gamma \delta} V_{G}^{P} \text { and } \\
V_{R}^{W} & =\frac{\left(k_{R}+\alpha \delta /(1-\delta)\right)(1-(1-\epsilon) \delta)}{(1-(1-\epsilon) \delta)(1-\gamma \delta)-\beta \epsilon \delta^{2}} \\
V_{R}^{P} & =\frac{e \delta}{1-\delta(1-\epsilon)} V_{R}^{W}
\end{aligned}
$$

By the optimality principle for dynamic programming, $\sigma^{F E}$ is a subgame perfect equilibrium if and only if no one-period deviation by either player after any history improves that player's payoff from that period forward. Given that it will not affect $R$ 's play under $\sigma_{R}^{F E}$, deviating to $c<1$ in a peace period only lowers $G$ 's payoff. For fighting rather than ceding autonomy to be optimal in a war period requires that $G$ have $V_{G}^{W} \geq 0$, which reduces to condition 1 in Proposition 1. In a peace period in which $G$ is weak, for $R$ to prefer to fight rather requires that $V_{R}^{P} \leq V_{R}^{W}$, which follows from (8) and $\delta<1$. For $R$ to prefer to fight rather than return to a peace period given $\sigma_{G}^{F E}$ requires that $V_{R}^{W} \geq 0$, which reduces to condition (2) in Proposition 1. QED.

Proof of Proposition 2. In a peace period, at least one deal exists that both $G$ and $R$ prefer to the Fight Equilibrium provided that there is a $c^{*} \in(0,1)$ such that $c^{*} /(1-\delta)>V_{G}^{P}$ and $\left(1-c^{*}\right) /(1-\delta)>V_{R}^{P}$. Such a $c^{*}$ exists if and only if $V_{G}^{P}+V_{R}^{P}<1 /(1-\delta)$. Using expressions 
(3) and (5) above, algebra shows that this inequality holds provided that $k_{G}+k_{R}<1$, which is assumed. A similar argument works for war periods.

Proof of Proposition 3. When conditions (1) and (2) obtain, $\sigma^{F E}$ constitutes an optimal penal code since it yields minmax payoffs forever after. So if an equilibrium path agreement on a history-dependent sequence of divisions of control $c_{t} \in[0,1]$ cannot be supported by the rebels' threatening reversion to $\sigma^{F E}$ if $G$ deviates from equilibrium path, then the rebels have no threat that can induce the government to choose anything other than $c=1$ in each period, which implies further that $\sigma^{F E}$ is unique.

Consider a given period $t$, which we can take as $t=0$ with no loss of generality. For a peaceful, subgame perfect equilibrium strategy to exist, it must be the case that (a) if $G$ is strong in this period, then $G$ has no incentive to deviate to a different $c_{t}$ than prescribed by the strategy, and (b) if the government is weak, that the rebels have no incentive to choose to fight, given the government's 'offer.' Condition (a) requires that

$$
c_{0}^{s}+E \sum_{j=1}^{\infty} c_{j} \delta^{j} \geq 1+\delta V_{G}^{P} .
$$

where $c_{0}^{s}$ is the division chosen by $G$ if the government is strong, $c_{j}$ is the division of power chosen in period $j$ under the proposed equilibrium strategy and the history of play to period $j$, and $E$ is the expectations operator. The right-hand side is the highest payoff $G$ can get by deviating given the reversion to $\sigma^{F E}$ in the next period. Similarly, condition (b) requires that

$$
1-c_{0}^{w}+E \sum_{j=1}^{\infty}\left(1-c_{j}\right) \delta^{j} \geq V_{R}^{W},
$$

where $c_{0}^{w}$ is $G$ 's offer in this period if weak.

Adding these two inequalities implies that

$$
c_{0}^{s}-c_{0}^{w}+\frac{\delta}{1-\delta} \geq \delta V_{G}^{P}+V_{R}^{W} .
$$

The largest possible value of the left-hand side is attained when $c_{0}^{s}=1$ and $c_{0}^{w}=0$, so that this necessary condition for a peaceful equilibrium cannot be satisfied if

$$
\frac{1}{1-\delta}<\delta V_{G}^{P}+V_{R}^{W}
$$

If inequality (14) is not satisfied, then a peaceful subgame perfect equilibrium can be constructed as follows: On the equilibrium path, have $G$ choose $c^{s}$ in all strong periods and $c^{w}$ in all weak periods, where these are chosen to satisfy (11) and (12) above (this is possible since the left-hand sides of (11) and (12) are linear in $c^{s}$ and $c^{w}$, which together with 
the reverse of (14) implies the claim). Off the path, $G$ and $R$ play the Fight Equilibrium. Conditions (1) and (2) ensure that neither player has an incentive to deviate to 'not fight' during a war (off the path). Condition (11) ensures that $G$ does not want to deviate to choosing 1 in a strong period (a fortiori $G$ does not want to deviate when $G$ is weak, since $V_{G}^{P}>V_{G}^{W}$ ). Condition (12) ensures that $R$ is receiving enough on the equilibrium path that it prefers not to deviate to fight when $G$ is weak. QED.

Proof of Proposition 4. (a) It is straightforward to check that the strategies described in the Proposition form a subgame perfect equilibrium whenever (1) holds and (2) does not (note that $k_{R}<-\delta(\alpha+\beta) /(1-\delta)$ is slightly stronger than condition (2)). We also know from Proposition 1 that we cannot support the Fight Equilibrium unless both (1) and (2) hold. So, to show uniqueness we need to show that it is not possible when (1) holds and $k_{R}<-\delta(\alpha+\beta) /(1-\delta)$ to construct an equilibrium in which the rebels at least sometimes get $c_{t}<1$ on the equilibrium path.

To induce $G$ to play $c_{t}<1$ in equilibrium, $R$ has to be able credibly to threaten to fight at the next opportunity. This requires that $R$ 's payoff for fighting after a deviation by $G$ is higher than for not fighting. $R$ can assure itself at least 0 by not fighting $(R$ 's minmax payoff when condition (2) fails). $R$ 's payoff for fighting to 'get back to' an equilibrium path is at most

$$
\hat{V}_{R}^{W}=k_{R}+\alpha \delta /(1-\delta)+\beta \delta /(1-\delta)+\gamma \delta \hat{V}_{R}^{W}
$$

Algebra shows that $\hat{V}_{R}^{W} \geq 0$ if and only if $k_{R} \geq-\delta(\alpha+\beta) /(1-\delta)$. QED.

(b) Exactly the same sort of argument applies here, regarding whether $G$ can credibly threaten to fight in order to return to an equilibrium deal when $R$ deviates by fighting if the government is weak. 
Table I. Estimated Median and Mean Civil War Duration by Region

\begin{tabular}{|lccc|}
\hline Region & Median & Mean & $\mathrm{N}$ \\
\hline E. Europe & 2.3 & 3.2 & 13 \\
N. Africa/M. East & 4.7 & 6.7 & 17 \\
W. Europe + US/Canada/Japan* & 6.0 & 8.5 & 15 \\
Latin America & 6.9 & 9.8 & 15 \\
SubSaharan Africa & 9.1 & 13.1 & 34 \\
Asia & 12.2 & 17.5 & 34 \\
\hline
\end{tabular}

${ }^{*} 13$ anticolonial wars + N. Ireland (1969-99) \& Greece 1945-49 


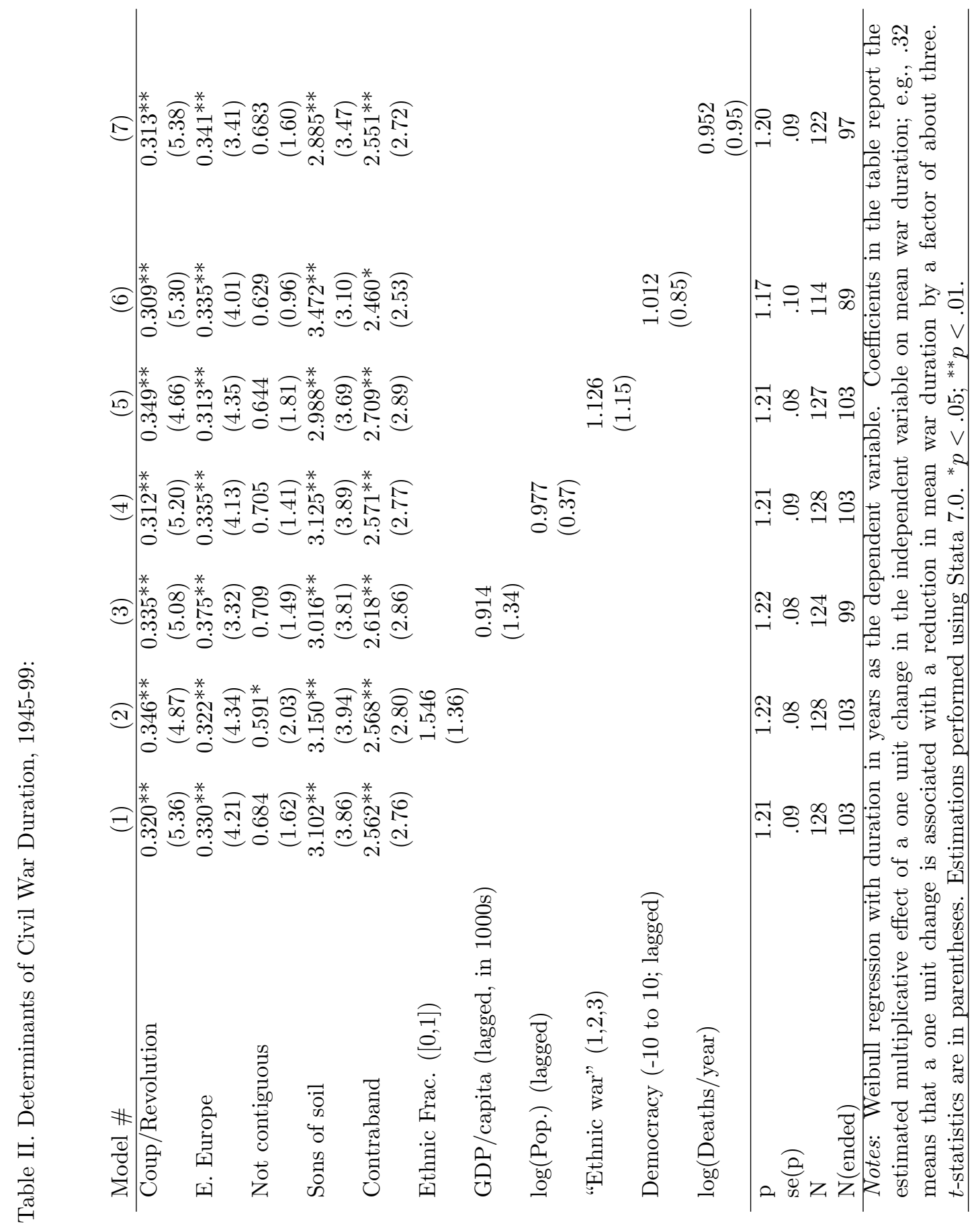


Table III. Multivariate Median and Mean Duration Estimates (in Years)

\begin{tabular}{|lcccc|}
\hline Attribute & Median & $95 \%$ c.i. & Mean & $95 \%$ c.i. \\
\hline Coup/Revolution & 2.5 & {$[1.6,3.8]$} & 3.1 & {$[2.1,4.8]$} \\
E. Europe & 2.5 & {$[1.5,4.3]$} & 3.2 & {$[1.9,5.5]$} \\
Not contiguous & 5.3 & {$[3.3,8.4]$} & 6.7 & {$[4.2,10.7]$} \\
$\begin{array}{l}\text { Sons of the Soil } \\
\text { Contraband finances }\end{array}$ & 23.9 & {$[13.3,43]$} & 30.4 & {$[16.9,54.7]$} \\
$\begin{array}{l}\text { Cases that have none } \\
\text { of these attributes }\end{array}$ & 7.7 & {$[10,39.1]$} & 25.1 & {$[12.7,49.8]$} \\
\hline
\end{tabular}

Note: Estimates are for a case with only the attribute listed and no others 
Figure 1. Number and Duration of Civil Wars in Progress

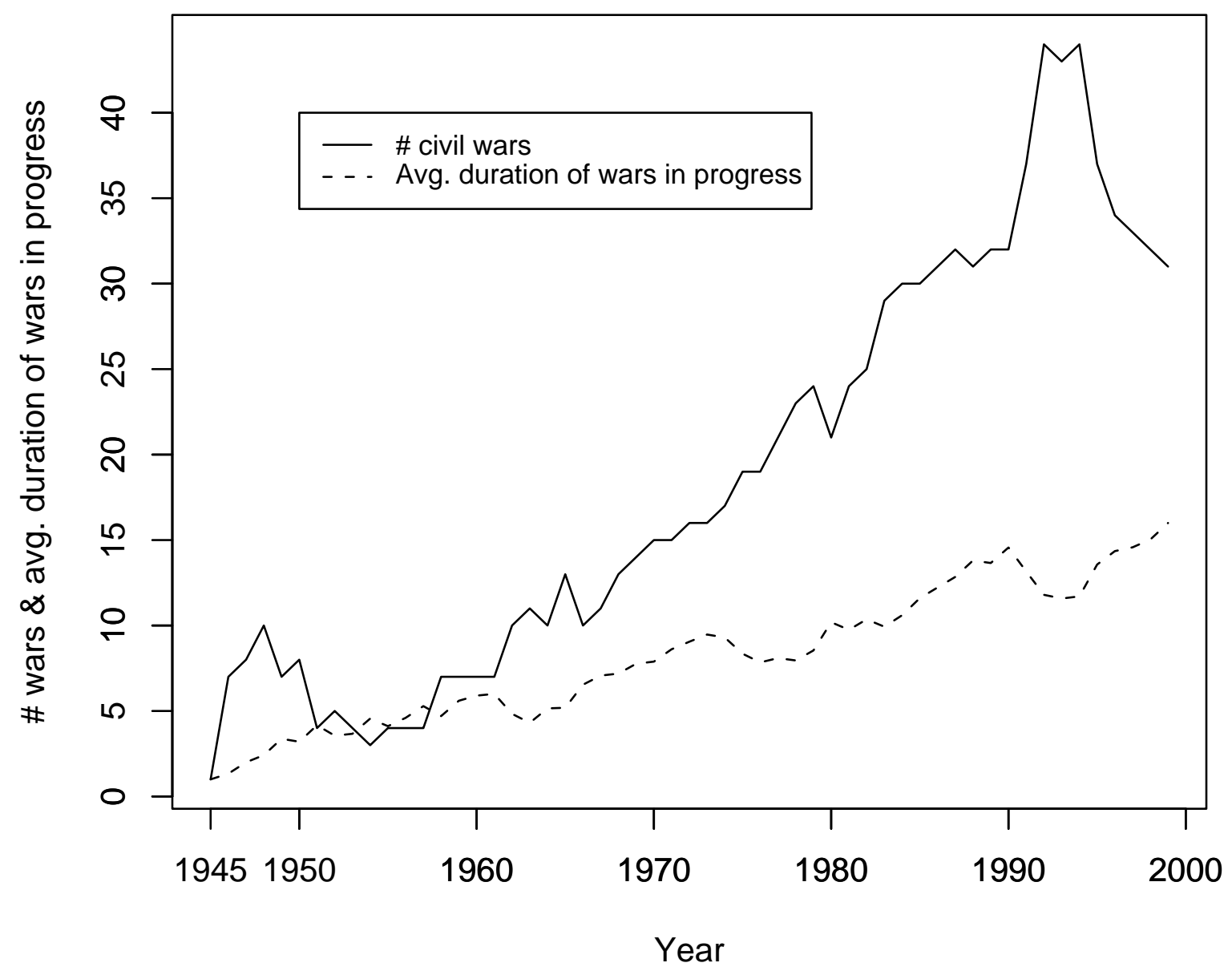


Figure 2. Proportion of Civil Wars Ongoing, by Year.
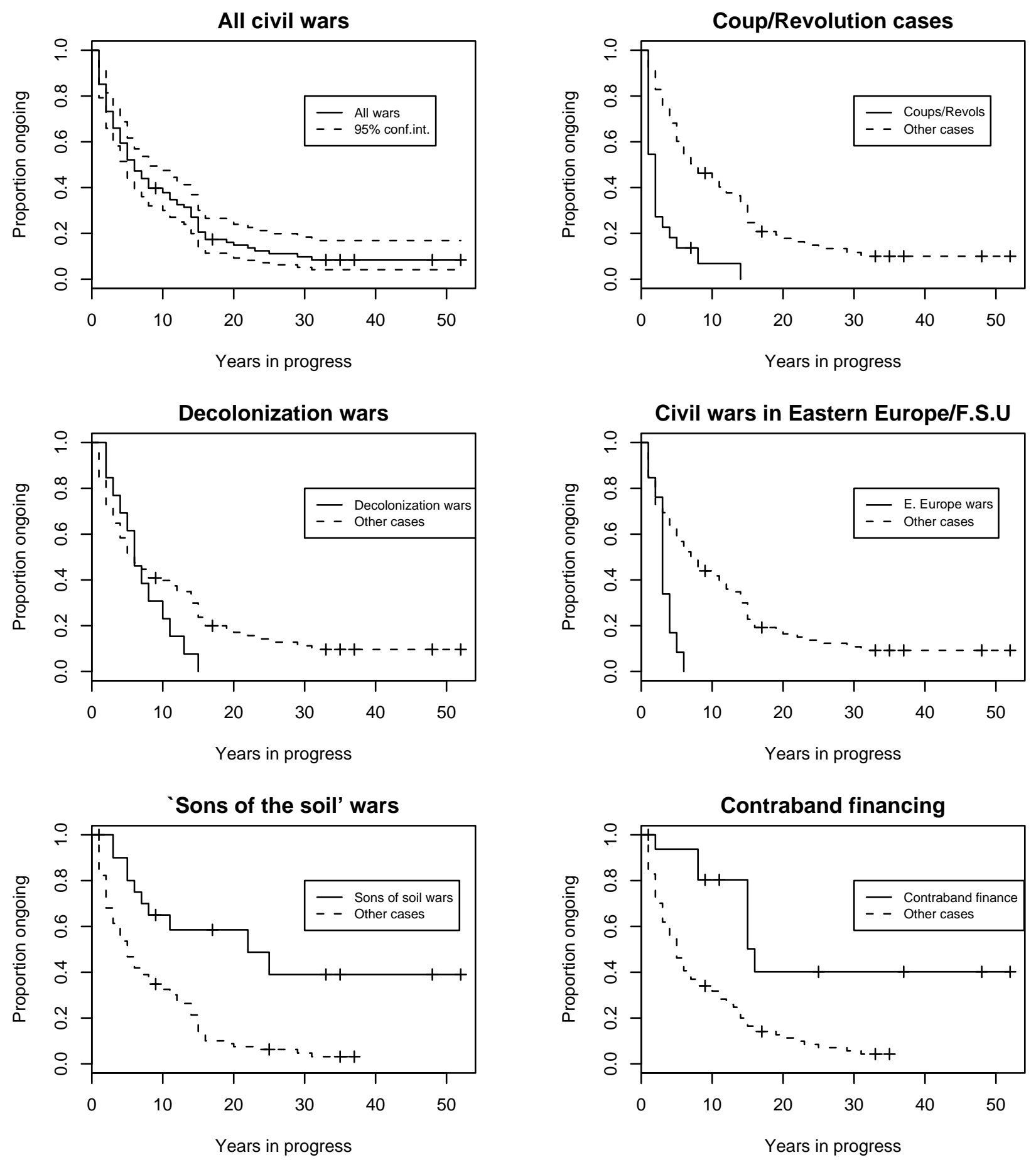
Figure 3. Rebellion or Peace in a Center-Region Bargaining Game.

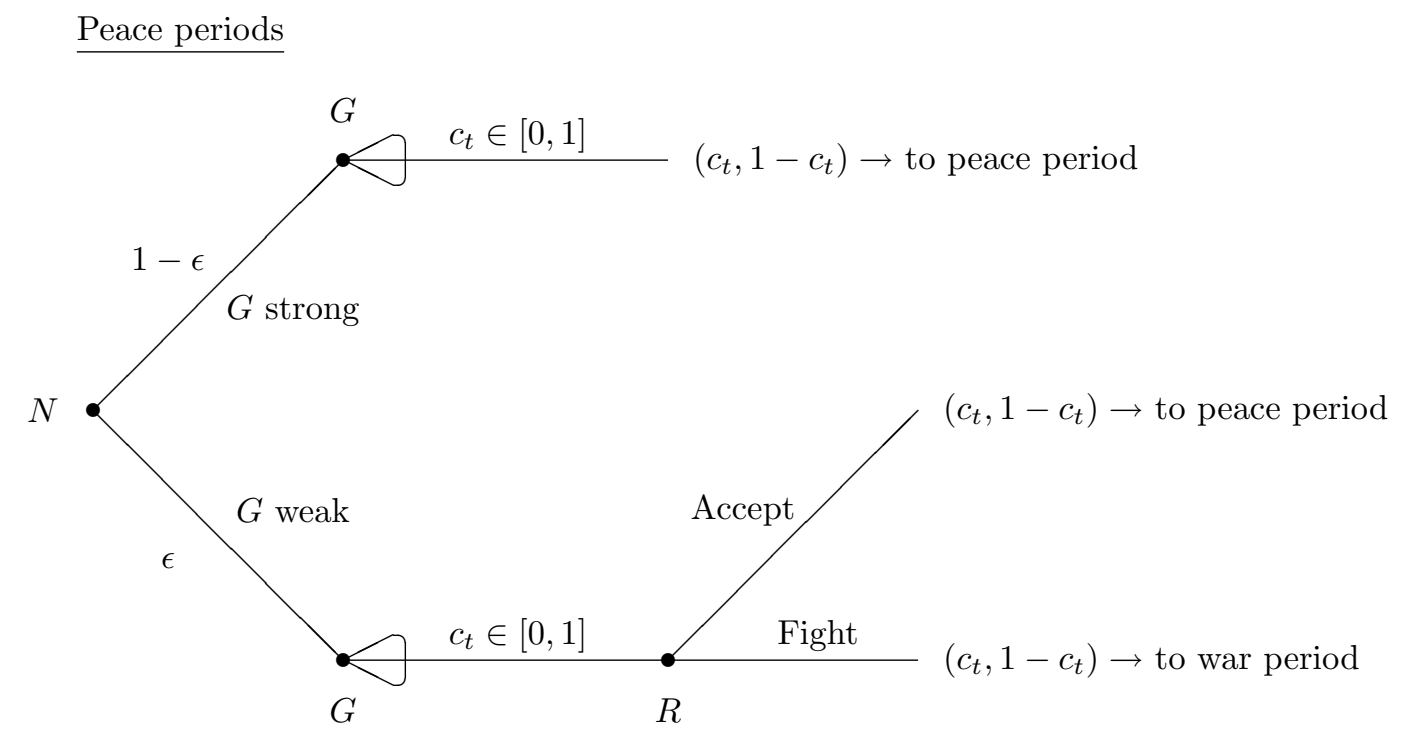

$\underline{\text { War periods }}$

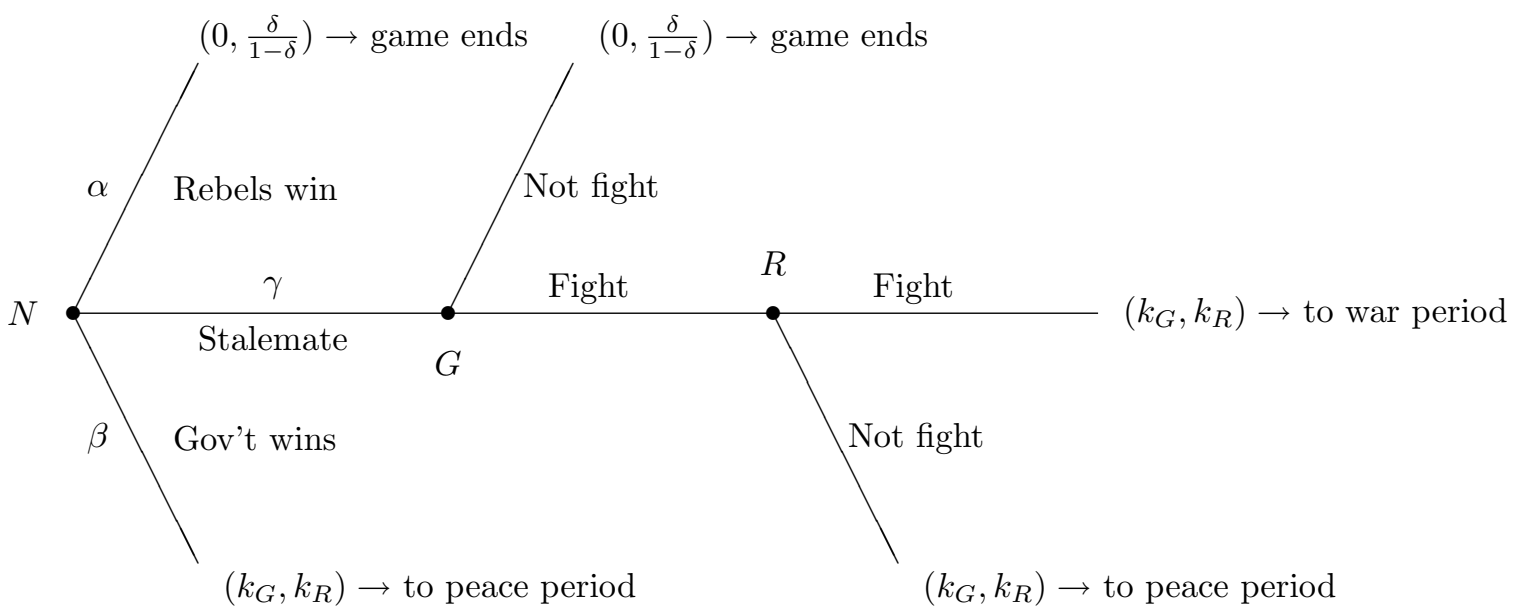




\section{References}

Acemoglu, Daron and James A. Robinson. 2001. "A Theory of Political Transitions." American Political Science Review 91(4):938-63.

Balch-Lindsay, Dylan and Andrew Enterline. 1999. "Prolonging the Killing? Third Party Intervention and the Duration of Intrastate Conflict, 1944-92." Presented at the 1999 Annual Meetings of the Western Political Science Association, Seattle, March 25-27.

Bennett, D. Scott and Alan C. Stam. 1996. "The Duration of Interstate Wars, 1816-1985." American Political Science Review 90(2):239-57.

Blainey, Geoffrey. 1973. The Causes of War. New York: Free Press.

Cann, John P. 1997. Counterinsurgency in Africa: the Portuguese way of war, 1961-1974. Westport, Conn.: Greenwood Press.

Collier, Paul and Anke Hoeffler. 2002. "Greed and Grievance in Civil War." World Bank, DECRG. http://econ.worldbank.org/programs/conflict.

Collier, Paul, Anke Hoeffler and Mans Söderbom. 2002. "On the Duration of Civil War." World Bank, DECRG. http://econ.worldbank.org/programs/conflict.

Doyle, Michael W. and Nicholas Sambanis. 2000. "International Peacebuilding: A Theoretical and Quantitative Analysis." American Political Science Review 94(4):778-801.

Eldabawi, Ibrahim and Nicholas Sambanis. 2000. "External Interventions and the Duration of Civil War." World Bank, DECRG. http://econ.worldbank.org/programs/conflict.

Esty, Daniel C., Jack A. Goldstone, Ted R. Gurr, Barbara Harff, Marc Levy, Geoffrey D. Dabelko, Pamela T. Surko and Alan N. Unger. 1998. State Failure Task Force Report: Phase II Findings. McLean, VA: Science Applications International Corporation.

Fearon, James D. 1994. Ethnic War as a Commitment Problem. Presented at the 1994 Annual Meetings of the American Political Science Association, 2-5 September, New York.

Fearon, James D. 1995. "Rationalist Explanations for War." International Organization 49(3):379-414.

Fearon, James D. 1998. Commitment Problems and the Spread of Ethnic Conflict. In The International Spread of Ethnic Conflict, ed. David A. Lake and Donald Rothchild. Princeton, NJ: Princeton University Press pp. 107-26.

Fearon, James D. 2003. "Comparative Statics Results for 'Why Do Some Civil Wars Last So Much Longer Than Others?'." Available at http://www.stanford.edu/group/ethnic/. 
Fearon, James D. and David D. Laitin. 2000. "Sons of the Soil,Immigrants and the State." Unpublished manuscript, Stanford University.

Fearon, James D. and David D. Laitin. 2003. "Ethnicity, Insurgency, and Civil War." American Political Science Review 97(1):75-90.

Galetovic, Alexander and Ricardo Sanhueza. 2000. "Citizens, Autocrats, and Plotters: A Model and New Evidence on Coups D'Etat." Economics and Politics 12(2):183-204.

Gleditsch, Nils, Havard Strand, Mikael Eriksson, Margareta Sollenberg and Peter Wallensteen. 2002. "Armed Conflict 1946-2001: A New Dataset." Journal of Peace Research $39(5): 615-37$.

Goemans, Hein. 2000. War and Punishment. Princeton, NJ: Princeton University Press.

Gurr, Ted Robert. 1996. "Minorities at Risk III Dataset: User's Manual." CIDCM, University of Maryland. http://www.cidcm.umd.edu/inscr/mar/home.htm.

IISS. 2000. The Military Balance, 2000. London: Institute for International and Strategic Studies.

Kaufmann, Chaim. 1996. "Possible and Impossible Solutions to Ethnic Civil Wars." International Security 20(4):136-175.

Lander, Mark. 2001. "State of Rebellion' Declared After Siege at Manila Palace." New York Times (National Edition) 2 May:A9.

Licklider, Roy A. 1995. "The Consequences of Negotiated Settlement in Civil Wars, 1945-93." American Political Science Review 89(3):681-90.

MacFarquhar, Neil. 2001. "Hamas asks Muslims to Back Suicide Raids." New York Times 11 December.

Powell, Robert. 2003. "The Inefficient Use of Power: Costly Conflict with Complete Information." Unpublished ms., U.C. Berkeley.

Sambanis, Nicolas. 2001. "Do Ethnic and Non-Ethnic Civil Wars Have the Same Causes? A Theoretical and Empirical Inquiry (Part 1)." Journal of Conflict Resolution 45(3):25982 .

Singer, J. David and Melvin H. Small. 1994. "Correlates of War Project: International and Civil War Data, 1816-1992." ICPSR 9905, April.

Sivard, Ruth Leger. 1996. World Military and Social Expenditures, 1996. Washington, DC: Global Priorities.

Tomz, Michael, Jason Wittenberg and Gary King. 1999. "CLARIFY: Software for interpreting and presenting statistical results. Version 1.2.1." Cambridge, MA: Harvard University, June 1. http://gking.harvard.edu. 
Valentino, Benjamin A. 2002. Final Solutions. Ithaca: Cornell University Press.

Wagner, R. Harrison. 2000. "Bargaining and War." American Journal of Political Science 44(3):469-84.

Walter, Barbara F. 1997. "The Critical Barrier to Civil War Settlement." International Organization 51(3):335-64.

Weiner, Myron. 1978. Sons of the Soil: Migration and Ethnic Conflict in India. Princeton, NJ: Princeton University Press.

Zartman, I. William. 1989. Ripe for Resolution: Conflict and Intervention in Africa. Oxford: Oxford University Press. 